Article

\title{
Exploring Advertising Effectiveness of Tourist Hotels' Marketing Images Containing Nature and Performing Arts: An Eye-Tracking Analysis
}

\author{
Tsai Chiao Wang ${ }^{1}$, Chia Liang Tsai ${ }^{1, *(\mathbb{D})}$ and Ta Wei Tang ${ }^{2, *}$ \\ 1 Institute of Physical Education, Health \& Leisure Studies, National Cheng Kung University, \\ No.1 University Road, Tainan City 701, Taiwan \\ 2 Department of Leisure and Recreation Management, Asia University, No. 500 Lioufeng Road, Wufeng, \\ Taichung City 413, Taiwan \\ * Correspondence: andytsai@mail.ncku.edu.tw (C.L.T.); twtang5@gmail.com (T.W.T.)
}

Received: 26 July 2018; Accepted: 21 August 2018; Published: 27 August 2018

\begin{abstract}
The beautiful, natural environment in a tourist hotel's marketing images can evoke relaxing and soothing emotions. However, can tourist hotels use nature as a servicescape to make their performing arts services more attractive? Based on attention restoration and servicescape theory, this study explores and compares the influence of tourist hotels' performing arts images with nature- or built-based servicescapes on the advertising effectiveness (i.e., customer visual attention and behavioral intention). To analyze visual attention on the marketing images, this study uses eye-tracking technology to record customer visual trajectories. This experiment used a total of 113 participants. The sample size of the nature-based servicescape group was 59 (age with mean $=39.04)$, and that of the built-based servicescape group was 54 (age with mean $=40.17$ ). A tourist hotel's (Volando Urai Spring Spa \& Resort) marketing images were chosen as stimuli. All participants were randomly assigned to the nature-based or the built-based servicescape group. In each experimental group, all the images were randomly presented to reduce any order effects of the images. By using eye-tracking analysis, the experimental findings were as follows: (1) A nature-based servicescape can arouse more visual attention of customers than a built-based servicescape can; (2) Marketing images with performing arts activities in nature-based servicescapes attract the visual attention of customers; (3) Nature-based servicescapes stimulate higher behavioral intentions of consumers than built-based servicescape.
\end{abstract}

Keywords: visual attention; eye-tracking; attention restoration theory; nature-based servicescape; behavioral intention

\section{Introduction}

The beautiful, natural environment in a tourist hotel's marketing images can evoke relaxing and soothing emotions [1]. However, can using the natural environment as a servicescape make a tourist hotel's performing arts services more attractive? Further, can photographs displaying performing arts along with nature make the tourist hotel's marketing images achieve higher advertising effectiveness? This issue is crucial for a tourist hotel to gain a sustainable competitive advantage, as performing arts is key for tourist hotels to provide memorable cultural experiences for their customers.

A servicescape refers to the physical environment affecting customer behavior [2], and it is also the basis for customers to evaluate hotels. To give customers a pleasurable service experience and consequently generate a good rating, hotel managers must design and build an attractive service environment to attract customers [3,4]. Servicescapes have been widely used in service designing in the hospitality industry, and have had a significant impact on the cultivation of hotel 
service environments [1,5]. A tourist hotel's surrounding environment is an important factor for designing a quality servicescape because it impacts the effectiveness of the overall service experience. In a servicescape design, nature-based [5] and built-based servicescapes [6,7] reside at the opposite ends of a continuum. Each of these are capable of attracting the visual attention of a particular set of consumers owing to their respective characteristics.

Individuals enjoy being close to beautiful, attractive natural environments that have more physical and/or psychological benefits [8,9]. Individuals prefer a natural environment because nature can help recover from stress or fatigue compared to built environments [10]. In the recovery psychology field, many studies have confirmed that the natural environment can provide better recovery results for individuals $[8,9,11]$. Additionally, in the hotel research field, the presence of a hotel's images is believed to be an important predictor of customers' attitudes toward the hotel, as they can get a rich holiday experience through the images [12,13]. Hotel managers want their marketing advertisements to attract and retain the attention of customers. How should performing arts be presented in images so that customers decide to make reservations with the hotel? This study explores the visual appeal of performing arts activities in nature-based and built-based servicescapes.

Images conveying information through art performances can make consumers feel new emotions and spend more time enjoying the content of the images. However, the stage of performing arts determines its appeal to consumers [14]. Attention restoration theory argues that the natural environment can help consumers relieve stress and fatigue. Consumers prefer to choose hotels that can help them relax. Furthermore, it is interesting that the natural environment may also help expand the effectiveness of performing arts. So far, no studies in the hospitality field have explored the relation between performing arts and the natural environment. This is crucial for hotel managers, as particularly, many tourist hotels are built in beautiful natural surroundings. In order to fill the gap in attention restoration theory, this study examines the impact of a combination of servicescapes and performing arts in a hotel marketing image on appealing consumers' visual attention and behavioral intentions.

Based on the servicescape and attention restoration theories, current research examines the effect of the makeup of nature-based servicescapes and performing arts images on a customer's visual attention and behavioral intention. Eye-tracking technology has become an important tool in the hospitality industry for examining customers' visual behavior [15]. It has proven effective in revealing customers' visual attention to hotel advertisements [13,16]. Therefore, Robson and Noone [17] have strongly recommended that future research in the hospitality industry use eye-tracking technology to objectively explore the relation between customers' eye movements and behavioral decisions. This study is the first one, to the researchers' knowledge, to use eye-tracking technology to investigate the influence of a servicescape and artist characteristics of hotel marketing images on customers' behavioral intentions. This study could replace subjective and intuitive rules in a scientific, objective way to compare the advertising effectiveness of images to enhance the insight of hospitality industry researchers and hotel managers on marketing image design.

\section{Literature Review}

\subsection{Hotel Marketing Images and Customer Visual Attention}

Images are used by hotels as key materials for marketing and advertising and are an important basis for evaluation for customers choosing a hotel $[13,15]$. However, given the limited time, customers will selectively observe the content of the images. Therefore, if the design of a hotel's marketing images can meet potential customers' needs and can capture their visual attention, it might further entice customers to consider making reservations with the hotel. For example, the study by Noone and Robson [16] found that customers are accustomed to choosing which hotel to reserve on the basis of the images that introduce the hotel's services, facilities, and other attributes.

The human visual system has a high limitation in handling the computational complexity and capacity of visual messaging [18]. Consumers search for their favorite hotels in a dense network of 
hotel advertisements. However, they often obtain too much information about hotel advertisements in the process, which is beyond the processing capability of an individual's visual system. The visual attention mechanism helps individuals focus only on the most important/relevant messages [19].

Visual attention is defined as the allocation of certain stimulus-information-processing abilities [20] and is used to describe an individual's selective behavior of seeing in the environment $[18,21]$. Attention also implies that individuals sacrifice certain things in order to effectively deal with other things. Visual attention is a selective process that assigns limited mental capabilities with regard to certain aspects of the visual environment while ignoring others [22]. Let the observer's attention shift from the entire image to the most significant or most interesting position [18].

If the image's features allow the observer to experience significant visual stimuli, the observer can generate attention [23]. The purpose of advertising is to first attract consumers' attention and then allow them to generate consumer behavior [24]. According to the AIDA model (Attention-InterestDesire-Action), only when travelers first focus on visual stimuli, do they generate interest and initiate further reactions to the visual stimuli $[24,25]$. Therefore, it is important to discuss how to design a picture so as to obtain the observer's visual attention.

A hotel's service is based on experience and intangibility. Buying accommodation services products is risky because individuals must make decisions based on images of service products [21,26]. Thus, the hotel's marketing manager heavily relies on the image to communicate with the customers. To design promotional advertisements that resonate with individuals, hotels can use elements in images to evoke their willingness to get an accommodation $[13,15]$. Therefore, researchers recently began using eye-tracking technology to explore the advertisement effectiveness of hotels [13,16,27-31]. Table 1 summarizes information about research papers using eye-tracking analysis in the hotel industry.

Table 1. Eye-tracking studies' focus, research subject, sample size, and interaction technique used as methods in hotel industry.

\begin{tabular}{|c|c|c|c|c|c|c|}
\hline \multirow{2}{*}{ Author(s) } & \multirow{2}{*}{ Focus } & \multirow{2}{*}{ Research Subject(s) } & \multirow{2}{*}{$\begin{array}{l}\text { Sample } \\
\text { Size }\end{array}$} & \multicolumn{3}{|c|}{$\begin{array}{c}\text { Interaction Technique Used } \\
\text { as a Method }\end{array}$} \\
\hline & & & & $\begin{array}{c}\text { Eye- } \\
\text { Tracking }\end{array}$ & Scale & Interview \\
\hline $\begin{array}{l}\text { Aicher, Asiimwe, } \\
\text { Batchuluun, } \\
\text { Hauschild, Zöhrer } \\
\text { and Egger [27] }\end{array}$ & $\begin{array}{l}\text { The question of how } \\
\text { pictures and text effect } \\
\text { online hotel reviews }\end{array}$ & $\begin{array}{l}\text { The subjects were students of the } \\
\text { Salzburg University of Applied } \\
\text { Sciences. }\end{array}$ & 16 & $\mathrm{v}$ & & \\
\hline $\begin{array}{l}\text { Hao, Tang, Yu, Li } \\
\text { and Law [28] }\end{array}$ & $\begin{array}{l}\text { Visual appeal of hotel } \\
\text { websites }\end{array}$ & $\begin{array}{l}\text { The age of the subjects ranged from } \\
19 \text { to } 35 \text {, who were MBA students of } \\
\text { a renowned university. }\end{array}$ & 53 & $\mathrm{v}$ & $\mathrm{v}$ & \\
\hline $\begin{array}{l}\text { Noone and } \\
\text { Robson [29] }\end{array}$ & $\begin{array}{l}\text { Consumers booking a } \\
\text { hotel online strategy }\end{array}$ & $\begin{array}{l}\text { They serve in university research } \\
\text { units and have experience in online } \\
\text { bookings for the past six months. }\end{array}$ & 32 & $\mathrm{v}$ & & \\
\hline $\begin{array}{l}\text { Noone and } \\
\text { Robson [16] }\end{array}$ & $\begin{array}{l}\text { Online travel agency } \\
\text { information pricing } \\
\text { strategy }\end{array}$ & $\begin{array}{l}\text { They have booked hotel online for a } \\
\text { tour trip using online resources for } \\
\text { the past six months. }\end{array}$ & 32 & $\mathrm{v}$ & & $\mathrm{v}$ \\
\hline $\begin{array}{l}\text { Pan, Zhang and } \\
\text { Smith [30] }\end{array}$ & $\begin{array}{l}\text { Online travel agency } \\
\text { customer information } \\
\text { search strategy }\end{array}$ & $\begin{array}{l}\text { They are faculty or staff members } \\
\text { an relatively highly educated with } \\
\text { online travel planning experience. }\end{array}$ & 41 & $\mathrm{v}$ & $\mathrm{v}$ & \\
\hline Pan et al. [13] & $\begin{array}{l}\text { Online travel agency } \\
\text { customer choice } \\
\text { strategy }\end{array}$ & $\begin{array}{l}\text { The subjects were faculty or staff } \\
\text { members in university. }\end{array}$ & 16 & $\mathrm{v}$ & & \\
\hline $\begin{array}{l}\text { Wang, Tsai and } \\
\text { Tang [31] }\end{array}$ & $\begin{array}{l}\text { Restoration quality of } \\
\text { hotel marketing } \\
\text { pictures }\end{array}$ & $\begin{array}{l}\text { Average age of approximately } \\
55 \text { years adults. }\end{array}$ & 80 & $\mathrm{v}$ & $\mathrm{v}$ & \\
\hline
\end{tabular}

\subsection{Attention Theory and Eye-Tracking Technology in the Hotel Industry}

Eye-tracking technology can be used to collect information related to customers' eye movements [32]. Eye movement plays an active role in their decision-making behaviors [33]. In eye-tracking analysis, "fixation" is a suitable measurement to describe customers' visual behavior when observing images [34,35]. 
In particular, the "duration" and "count" of fixation are the two most suitable parameters for describing customers' visual attention preference [32,36]. First, the longer the fixation duration, the more time is spent by individuals on deciphering the information or connecting internal and external representations [35,37]. For example, when visitors spend more time gazing at a travel image, it indicates that they take interest in the travel destination depicted in the image or would like to travel to that destination [38]. Second, the higher the fixation count, the more attractive is the information $[35,36]$. For example, when customers browse web pages to choose hotels, the more frequently they observe the description of a particular hotel, the more interested they are in that hotel, and they are also likely to make reservations with the hotel [13]. Therefore, information such as the target, count, and duration of fixation can indicate where the individual's attention is concentrated in the image and indicate which are the most important messages in the image [21].

By using the eye-tracking technology, hotel managers can see customers' internal decision-making process as well as behavioral intention. To effectively capture customers' visual attention, the hospitality industry has recently begun using the eye-tracking technology to examine the visual behavior displayed by customers (e.g., $[13,15])$.

\section{Hypothesis}

\subsection{The Impact of Different Servicescape Characteristics with Performing Arts on Visual Attention}

Performing arts services can serve as a source of differentiation strategies for hotels and provide a memorable experience to consumers [5]. The "fascination" element of the natural environment can assist performing arts in getting the attention of individuals more easily [8,39], and can make it easier for consumers to discover the value of artistic performance. Therefore, a nature-based servicescape can enhance the value that the performing arts offers to consumers. Combining performing arts with a nature-based servicescape is a strategy that effectively enhances customer value. However, the same performing arts do not have the same effect in built environments, such as in a hotel lobby or hallway, because in a hotel's built environment, the hotel cannot provide a fascinating feeling to consumers. Artificial scenes are not successful at attracting more visual attention and cannot contribute to recovery from consumer mental fatigue [8]. In this context, built-based servicescape as a background for performing art images will not significantly enhance the consumer's visual attention.

As found in the research by Bahia et al. [40], scenarios can improve the value and service quality provided by core services to the customers. Beautiful scenarios can attract the consumer's visual attention, and direct the consumer's attention from the images of other hotels to the hotels with beautiful environments and their core services. Thus, hotel marketing images that provide nature-based servicescape as a background for performing arts will be better than a built-based servicescape as a background for performing arts to capture consumers' visual attention.

Hypothesis 1 (H1). Compared to performing art images with the built-based servicescapes as background, those with nature-based servicescapes as background can to get a higher visual attention.

\subsection{The Impact of Different Servicescape Characteristics with Performing Art on Behavioral Intentions}

Limited travel studies explicitly test individual preferences for hotel images in different service scenarios [21], although a hotel may care and try to stimulate the consumer's behavioral intentions. For example, by using a survey, Nadeau et al. [41] explored the impact of individual beliefs about natural and built environments on the assessment of tourism imagery in tourist destinations. They found that both natural and built environment beliefs will enhance the concerned destination's evaluation, which results in higher travel intentions from consumers. However, previous studies have suggested that natural environments can bring more psychological benefits.

Fascination with the natural environment (for example, walking in the forest and watching the flow of dark green water) can easily attract the attention of an individual and stimulate him/her to 
want to get close to nature and have a chance at recovery [31,42]. The urban environment does not provide more "going out" stimulus to generate the same recovery opportunities $[8,10]$.

Previous studies have found that individuals tend to prefer an environment in which they can recover from mental fatigue [42-44] and even want to experience the environment. Nature-based servicescapes encourage consumers to go there and enjoy the effect of relieving pressure. The hotel offers performing arts services that enriches the beauty of the natural environment and provides more meaning, mystery, and cultural experience to its customers. By providing customers with such a service with nature-based servicescapes, they will enjoy the cultural experience of performing arts and recovery effect of the natural environment.

Individuals favor nature for the relaxation and stress-soothing function. Individuals seldom see beautiful, natural environments in urban areas. When travelers see the beautiful pictures of natural landscapes of a hotel, their fascination for nature is aroused, and hence their positive emotions toward the hotel are stimulated. These positive emotions will improve their assessment of the hotel prior to the journey, consequently improving their preference and behavioral intention [26,31].

Both the beautiful environment and performing art can reinforce each other, thereby enhancing the customers' preferences for hotel performing arts services. The use of the natural environment as a stage for performing arts can encourage customers to be present at the hotel to enjoy performing arts or to recommend this performance service to others. Therefore, hotels' marketing pictures that provide natural clues can drive individuals to collect more information about the performing arts and services of hotels and can enhance their willingness to experience performing arts in hotels. The hotel marketing pictures that provide natural clues will be better than providing built clues to make observers want to experience and see more performing arts, resulting in observers to choose to stay in hotels or put this hotel in the priority list.

Hypothesis 2 (H2). Compared with performing art images with the built-based servicescapes background, the performing art images with nature-based servicescapes background will be able to get a higher behavioral intention from customers.

The proposed hypotheses are illustrated in Figure 1.

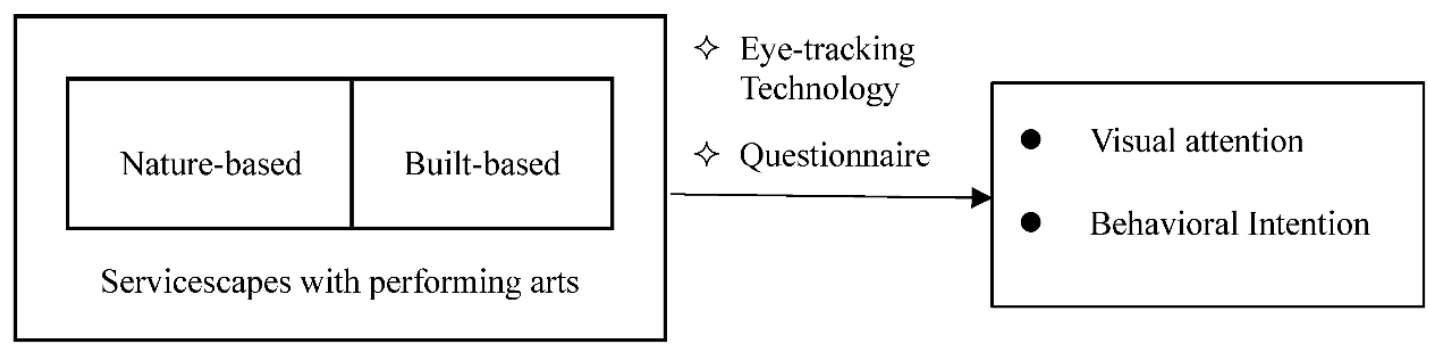

Figure 1. Research concept model.

\section{Method}

\subsection{Stimulus}

Volando is a rare member of Relais \& Chateaux (R\&C) in Taiwan. The hotel provides several performance art activities to its customers and allows them to watch them in a comfortable environment. Each performing art takes approximately 10-30 min. Descriptions for 24 performing arts images of the hotel marketing advertising were generated from the Volando Urai Spring Spa \& Resort (Volando). Consequently, Volando's marketing advertising images were chosen as the stimulus.

To identify the servicescape (nature- or built-based) classification, each expert (customers $=5$, hotel manager $=2$, scholar $=5$ ) rated each marketing advertising image on a five-point scale (totally nature-based environment $=5$, totally built-based environment $=1$ ) [45]. 


\subsection{Sample}

In total, 140 individuals participated in this study. All participants were healthy adults who were invited to the eye-tracking study. We only tested adults because they are the key to choosing and ordering the hotels $[12,13]$. Participants were recruited via web announcements.

To optimize the experiment, the recruitment criteria for the test participants of this study included the following: First, was normal visual acuity or best corrected visual acuity (visual above 0.8 as a standard metric), to ensure accuracy in capturing eye-movement data [46]. Second, were adult participants aged 20 years or more who did not have a student status. Third, participants were mainly first-time visitors to the case hotel to avoid past experiences and memories affecting the participants' accurate judgment of the advertisement effectiveness [47]. Written informed consent was obtained from all participants.

The total effective sample size of this study was 113. The average age of the sample was 39.64 years (Male $=64$, Female $=49, \mathrm{SD}=11.88$ ). The sample size of the nature-based servicescape group was 59 (age with mean $=39.04 ; \mathrm{SD}=11.8$ ), and the sample size of the built-based servicescape group was 54 (age with mean $=40.17 ; \mathrm{SD}=12.02$ ). The effective sampling rate is $80.74 \%$.

We used $G^{*}$ pwer analysis to check if the sample was sufficient for the validation of the study hypothesis. The analysis showed that the sample size and characteristics of this study were sufficient for hypothesis testing. In addition, Scott et al. [48] reviewed eye-tracking research in the tourism field and found that eye-tracking research designs have been used with between 12 and 63 participants. The present study's sample (113 participants) was larger than the sample (between 12 and 63 participants) used in previous studies. Based on previous research samples and $G^{*}$ power analysis results, the sample size of this research was sufficient for examining the hypothesis.

\subsection{Behavioral Intention Scale}

Behavioral intention reflects consumers' positive attitudes toward hotels. The questionnaires developed by Harris and Ezeh [49] were adapted to create a scale to measure behavioral intention. Five items were included, and the value of Cronbach's alpha was 0.87 .

This study verified the following indicators suggested by Hair et al. [50], including the reliability, composite reliability (CR), and average variance extracted (AVE) to confirm the reliability and convergent validity of the behavioral intention scale. First, the factor loadings of all the observed variables achieved significance ranging from 0.69 to 0.80 , exceeding the criterion of 0.5 recommended by Hair et al. [50], thus showing satisfactory reliability. Second, Hair et al. [50] suggested that CR exceed 0.7 . The $C R$ of behavioral intention was 0.87 , thus indicating satisfactory internal consistency. Third, the AVE value of behavioral intention was 0.58 , exceeding the criterion of 0.5 recommended by Fornell and Larcker [51], thus demonstrating satisfactory convergent validity.

\subsection{Procedure}

This study used static stimuli for the experiment and an eye-tracking device to record customer eye-movement data when viewing hotel marketing advertising images. Participants sat about $60 \mathrm{~cm}$ away from the computer monitor and wore ear protection to reduce noise. The stimuli images appeared on a 22-inch widescreen monitor with a resolution of $1920 \times 1080$ pixels. Before formally collecting eye-tracking data, a 9-point calibration procedure was used. All participants were randomly assigned to the nature-based servicescape or built-based servicescape groups. In each experimental group, all of the images were randomly presented to reduce any order effects of images. After the eye-movement experiment, each participant was asked to provide personal background information. The experiment was controlled with eye-tracking software. The experimental participants' eye-movement data was also exported with the software. 


\section{Results}

\subsection{Servicescape and Performing Art}

As shown in Figure 2, nature-based servicescapes attracted more customers' visual attention than the built-based servicescapes did, indicating that it was easier to attract customers' visual attention using the nature-based servicescapes created by hotels.

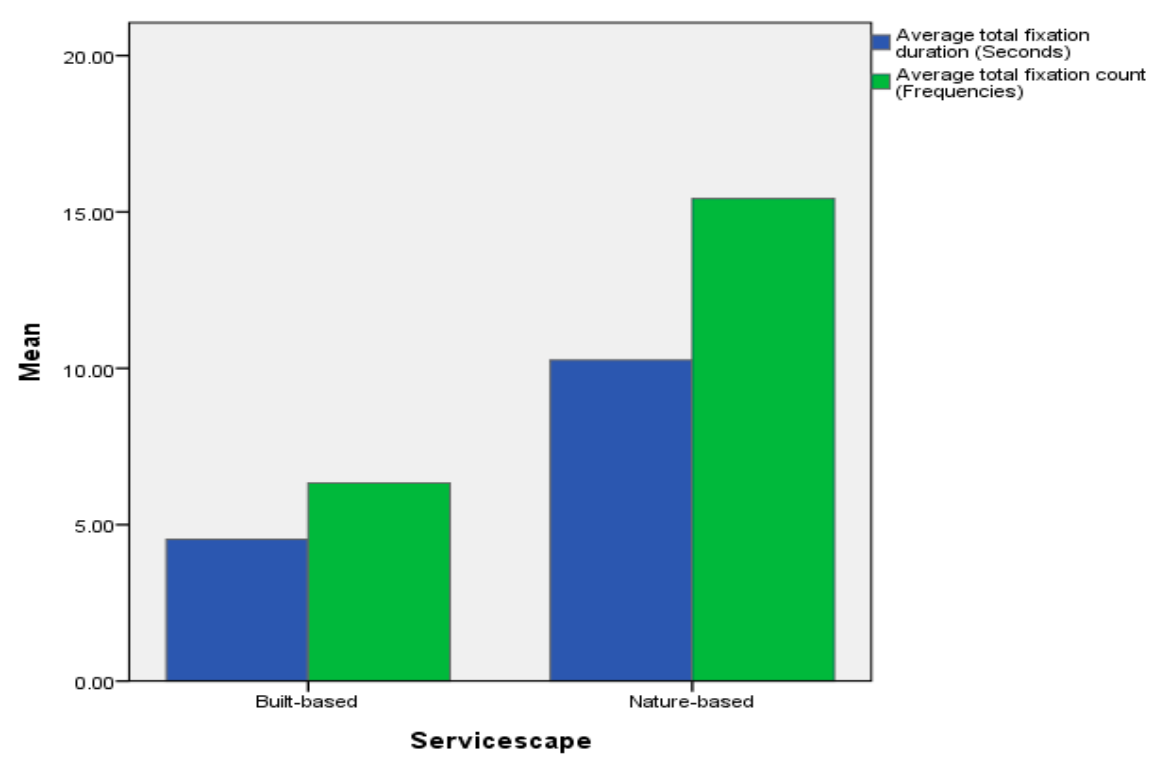

Figure 2. Bar charts of customers' visual attention on the servicescape.

In addition, through a $t$-test analysis, this study shows how the marketing advertising of performing arts and servicescapes can best attract customers' visual attention. From Figure 3, the average fixation duration and the average fixation count of the participants for the nature-based servicescape after adding the performing art activities' images are still higher than those of the participants for the built-based servicescape.

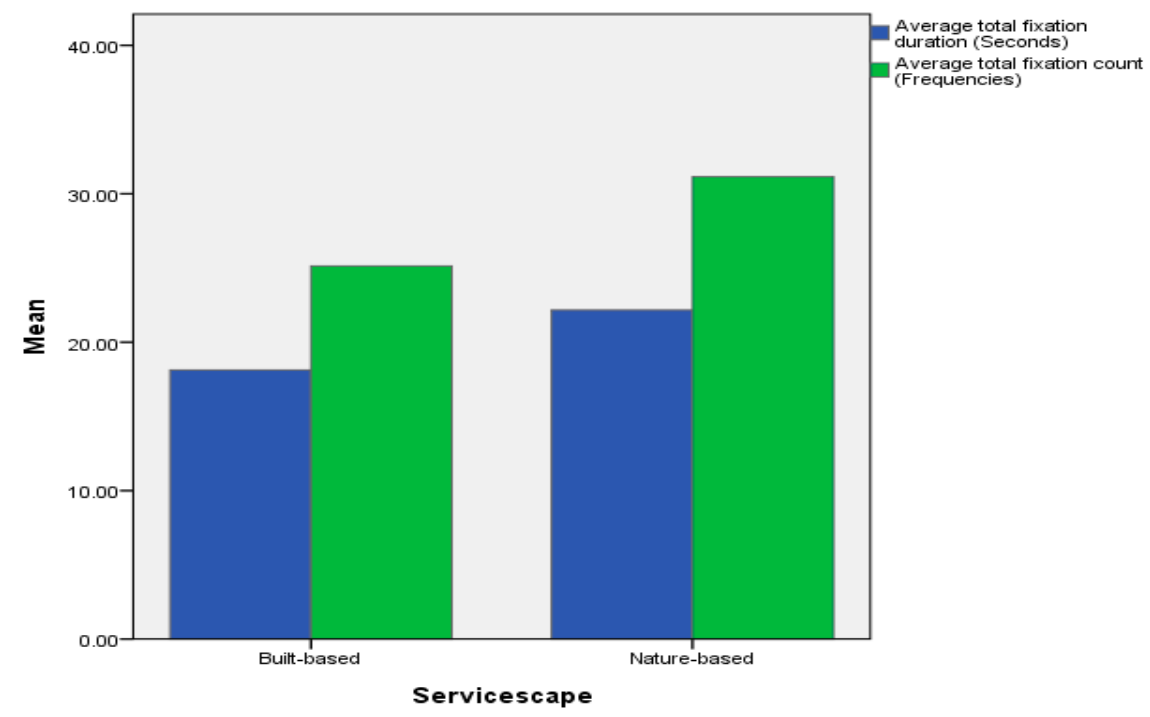

Figure 3. Bar chart of customers' visual attention on performing arts with servicescapes. 
Additionally, this study used line charts to illustrate how performing arts combined with a servicescape can affect the customer's visual attention. When servicescapes are combined with performing arts activities, customers face similar images with a noticeable improvement in the average fixation duration and the average fixation count in Figure 4. As a result, the hotels that used performing arts as the main part of the marketing advertisement and combined the nature-based servicescapes with the advertisement background, attracted customers' visual attention more than the hotels that used built-based servicescapes as the advertisement background. Therefore, compared with performing arts images with the built-based servicescape backgrounds, the performing art images with nature-based servicescape backgrounds will be able to get a higher visual attention. Therefore, Hypothesis 1 is supported.

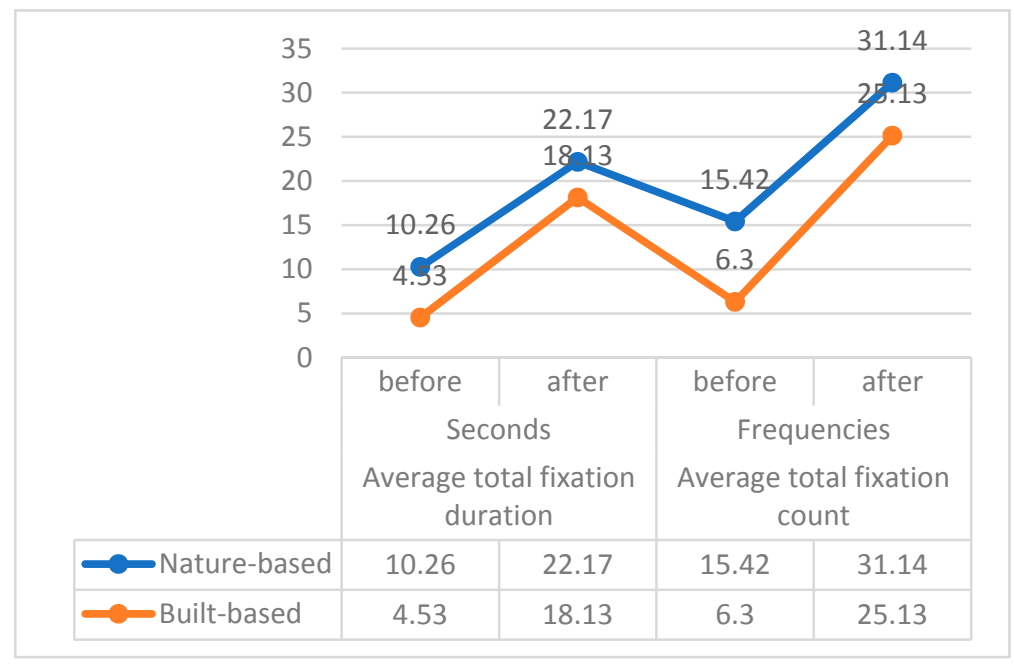

Figure 4. Influence on customers' visual attention from performing arts and servicescapes.

\subsection{Behavioral Intentions}

$T$-test analysis was used to test the impact of nature-based servicescapes and built-based servicescapes on customer behavior intentions (see Table 2).

Table 2. The impact of servicescapes on customer behavioral intentions.

\begin{tabular}{ccccc}
\hline Servicescape & Means & $t$ & $t$-Test Results \\
\cline { 1 - 2 } Nature-based servicescape with performance arts & 4.53 & \multirow{2}{*}{$2.68^{* *}$} & Nature-based $>$ Built-based \\
\cline { 1 - 2 } Built-based servicescape with performance arts & 4.24 & & \\
\cline { 1 - 2 }${ }^{* *} p<0.01$. & &
\end{tabular}

The impact of performing arts displayed within nature-based servicescape stimulated customers to be more willing to recommend the hotel to their friends, consider the hotel as their first choice hotel, appreciate the hotel in front of other people, encourage friends and relatives to go to the hotel, and do more travel activities with the hotel in the next few years. In summary, nature-based servicescapes with performing arts can stimulate customers to generate higher behavioral intentions than built-based servicescapes with performing arts. Therefore, Hypothesis 2 is supported.

\section{Discussion and Conclusions}

To the best of the researchers' knowledge, this study is the first one to use eye-tracking technology to explore the influence of the servicescape and artist characteristics of tourist hotel pictures on individual behavioral intentions. The study results can benefit researchers in the hospitality industry and hotel advertising designers as follows. 
First, in order to make use of the limited marketing resources effectively, service transaction analysis (STA) introduced by Johnston [52] suggested that decision-makers combine opinions of managers and customers to examine the attractiveness of services. This study argues for this suggestion and uses eye-tracking analysis technology to capture objective visual data from customers (i.e., opinions of customers). Particularly, the results indicate that consumers have higher fixation durations and counts for nature-based images than built-based images, and the behavioral intention after watching nature-based images is higher than that after watching built-based images. This result suggests that visual attention is a predisposition for consumer's decision-making. The eye-tracking technology can capture a consumer's allocation of attention while watching the hotel's advertisement. Therefore, for hotel's marketing managers, eye-tracking data are conducive to a better marketing strategy based on the actual viewing data of the consumers, instead of solely depending on the opinions of hotel's marketing managers. Combining the research orientation of hotels' marketing strategies and eye-tracking analysis technology is an innovative research approach. The eye-tracking analysis method can directly understand consumers' reactions to the hotel marketing strategy.

Second, the findings of the eye-tracking study revealed that the current study demonstrates that a nature-based servicescape is the key to attracting customers' visual attention.

Customers will pay attention to the images of an environment rife with greenery [16]. As found in the research conducted by Hartig et al. [53], the interaction of individuals with the natural environment can improve their mood and focus and leads to numerous positive health and restorative outcomes. In addition, the marketing images within nature-based servicescapes are able to attract twice the fixation duration and fixation count as opposed to those within the built-based servicescape. As found in the research by Cheng et al. [5], hotels can attract more visual attention from customers, enhance their experience, and in turn increase the value of their overall service experience by staging performances rich in local traditions and culture in a nature-based ambience [39,54]. Consequently, incorporating nature-based servicescapes as design elements in advertisements can benefit tourist hotels by increasing the effectiveness in advertising and attracting customers' visual attention.

Third, combining nature-based servicescapes with performing arts to design marketing activity advertising is more effective in creating visual attraction than combining built-based servicescapes with performing arts. These findings are similar to what Cheng et al. [5] discovered. In other words, the more seamless a fit between the servicescape and performing art, the greater is the advertising effectiveness of the marketing images. The researchers found that despite the same performance, staging it in different servicescapes (nature- or built-based) could convey different messages to the audience. Therefore, hotel operators should recognize that customer experience stems from the harmony between the actual natural environment and performing arts [39] and strives to strike a balance between the stage and the performing art itself. These findings are similar to that of Chang [1].

Fourth, this study suggests that tourist hotels should present performing arts or nature-based servicescapes on marketing images in order to make customers feel pleasant emotions. Marketing images considerably influence customers' visual attention and emotional responses [16]. Those tangible clues in images can convey invisible experiences to customers. When hotels present services on marketing images that make customers feel novel and relax, they can attract customers' visual attention and temporarily relieve their fatigue. Therefore, customers are more willing to list hotels that can combine natural and artistic performances as a priority list, to have more frequent accommodations at this hotel, and even more willing to recommend this hotel to their friends. When a hotel can offer a unique service combining natural servicescapes and artistic performances to its customers, these customers will also have positive behavioral intentions toward the hotel.

This study confirms consumer preferences and behavioral intentions for these characteristics, which significantly contributes to the development of hotel marketing and business management practices and the service innovation theory in hotel field.

Finally, this study explores the research of performing arts in the context of marketing advertising research for hotels. Previous studies have found that beautiful nature could improve customer's 
evaluations of core service or even service quality [31,39,42]. Furthermore, as found in Hume et al. [55] qualitative research on performing arts in non-profit organizations, functional factors and service quality were key factors influencing consumer's decision of repurchasing intention. Organizations providing performing services have their strategy focused on emotional attainment and show experience, which are, in general, not important for consumer's decision of repurchasing intention. This study has similar findings-hotel's images of performing arts combining natural environment can convey the message of better service quality to customers-as suggested by Wang et al. [31]. They also convey to the customers that the hotel is equipped with an environment in which mental fatigue can be alleviated; hence, the behavioral intension of customers is influenced. This result may suggest that a sustainable development of nature is conducive to quality service and provides higher value by the hotel to their consumers.

Images providing clues of beautiful nature not only re-allocate the duration of a consumer's observing time but also strengthen their behavioral intention toward the hotel. These beautiful natural environments can enhance the value and attractiveness of the core service. They can also convey the message that the hotel provides core experience service in natural ambience, thus promoting good evaluation during decision-making process and relatively high positive intention of customers. Results of this study contribute to the hotel's marketing strategy of performing arts as well as to the research in the field of innovative service. The results also suggest hotel managers develop attractive core services for their target customers amidst a beautiful natural environment.

Future research in the innovative service field should focus on not only the process of tourist hotel development and innovate services, but also the exploration of the services that have the content or characteristics that appeal to customers. Customers are attracted to new service offerings that are unique and highly value-added and not just service characterizations that are low value but different from other hotels.

Marketing managers are constantly trying to discover tangible visual cues that can stimulate customer behavioral intentions. The results of this study suggest that hotels can find ways to combine their tourism resources and artistic performances. This can also serve as a way to develop innovative services. Through this method, tourist hotels can direct or enhance customers' positive behavioral intention.

\section{Research Limitations and Future Research}

As in any research, there were some limitations of this study. First, this study did not measure gender, age, or mental health, which as factors might play a large role in the differences of the participants. Future research is needed to take more demographic information into account. Second, the performing art place used in this study is surrounded by a natural environment. Consequently, the research findings may not be applicable to sports places that are not surrounded by nature. Third, researchers can use video advertising as the stimulus to examine customers' visual attention in order to gain a more complete picture of customers' eye movements.

Author Contributions: Conceptualization, T.C.W., C.L.T. and T.W.T.; Data curation, T.C.W., C.L.T. and T.W.T.; Methodology, T.C.W., C.L.T. and T.W.T.; Resources, T.C.W. and C.L.T.; Software, T.C.W. and C.L.T.; Writing—original draft, T.C.W. and T.W.T.; Writing—review \& editing, C.L.T. and T.W.T.

Funding: This research is partially supported by [Ministry of Science and Technology, Taiwan] grant number [MOST 105-2410-H-006 -050 -MY3 and MOST 106-2811-H-006-014].

Conflicts of Interest: The authors declare no conflicts of interest.

\section{References}

1. Chang, K.C. Effect of servicescape on customer behavioral intentions: Moderating roles of service climate and employee engagement. Int. J. Hosp. Manag. 2016, 53, 116-128. [CrossRef]

2. Bitner, M.J. Servicescapes: The impact of physical surroundings on customers and employees. J. Mark. 1992, 56, 57-71. [CrossRef] 
3. Countryman, C.C.; Jang, S. The effects of atmospheric elements on customer impression: The case of hotel lobbies. Int. J. Contemp. Hosp. Manag. 2006, 18, 534-545. [CrossRef]

4. Lin, I.Y. Evaluating a servicescape: The effect of cognition and emotion. Int. J. Hosp. Manag. 2004, 23, $163-178$. [CrossRef]

5. Cheng, J.S.; Tang, T.W.; Shih, H.Y.; Wang, T.C. Designing lifestyle hotels. Int. J. Hosp. Manag. 2016, 58, 95-106. [CrossRef]

6. Mun Lim, W.; Endean, M. Elucidating the aesthetic and operational characteristics of UK boutique hotels. Int. J. Contemp. Hosp. Manag. 2009, 21, 38-51. [CrossRef]

7. Aggett, M. What has influenced growth in the UK's boutique hotel sector? Int. J. Contemp. Hosp. Manag. 2007, 19, 169-177. [CrossRef]

8. Kaplan, S. The restorative benefits of nature: Toward an integrative framework. J. Environ. Psychol. 1995, 15, 169-182. [CrossRef]

9. Kaplan, R. The nature of the view from home: Psychological benefits. Environ. Behav. 2001, 33, 507-542. [CrossRef]

10. Ulrich, R.S.; Simons, R.F.; Losito, B.D.; Fiorito, E.; Miles, M.A.; Zelson, M. Stress recovery during exposure to natural and urban environments. J. Environ. Psychol. 1991, 11, 201-230. [CrossRef]

11. Honold, J.; Lakes, T.; Beyer, R.; van der Meer, E. Restoration in urban spaces: Nature views from home, greenways, and public parks. Environ. Behav. 2016, 48, 796-825. [CrossRef]

12. Jeong, M.; Choi, J. Effects of picture presentations on customers' behavioral intentions on the web. J. Travel Tour. Mark. 2005, 17, 193-204. [CrossRef]

13. Pan, B.; Zhang, L.; Law, R. The complex matter of online hotel choice. Cornell Hosp. Quart. 2013, 54, 74-83. [CrossRef]

14. Swanson, S.R.; Davis, J.C. Delight and outrage in the performing arts: A critical incidence analysis. J. Mark. Theory Pract. 2012, 20, 263-278. [CrossRef]

15. Scott, N.; Green, C.; Fairley, S. Investigation of the use of eye tracking to examine tourism advertising effectiveness. Curr. Issues Tour. 2016, 19, 634-642. [CrossRef]

16. Noone, B.M.; Robson, S.K. Understanding Consumers' Inferences from Price and Nonprice Information in the Online Lodging Purchase Decision. Serv. Sci. 2016, 8, 108-123. [CrossRef]

17. Robson, S.K.; Noone, B. Show me what you see, tell me what you think: Using eye tracking for hospitality research. Cornell Hosp. Rep. 2014, 14, 6-12.

18. Engelke, U.; Le Callet, P. Perceived interest and overt visual attention in natural images. Signal Process. Image Commun. 2015, 39, 386-404. [CrossRef]

19. Wolfe, J.M. Visual Attention. In Seeing, 2nd ed.; DeValois, K.K., Ed.; Academic Press: San Diego, CA, USA, 2000; pp. 335-386.

20. Zaltman, G.; Coulter, R.H. Seeing the voice of the customer: Metaphor-based advertising research. J. Advert. Res. 1995, 35, 35-51.

21. Sparks, B.A.; Wang, Y. Natural and built photographic images: Preference, complexity, and recall. J. Travel Tour. Mark. 2014, 31, 868-883. [CrossRef]

22. Carrasco, M. Visual attention: The past 25 years. Vis. Res. 2011, 51, 1484-1525. [CrossRef] [PubMed]

23. Nothdurft, H.C. The role of features in preattentive vision: Comparison of orientation, motion and color cues. Vis. Res. 1993, 33, 1937-1958. [CrossRef]

24. McWilliams, E.G.; Crompton, J.L. An expanded framework for measuring the effectiveness of destination advertising. Tour. Manag. 1997, 18, 127-137. [CrossRef]

25. Morosan, C. The influence of DMO advertising on specific destination visitation behaviors. J. Hosp. Mark. Manag. 2015, 24, 47-75. [CrossRef]

26. Kotler, P.; Bowen, J.T.; Makens, J.C.; Baloglu, S. Marketing for Hospitality and Tourism; Prentice Hall: Upper Saddle River, NJ, USA, 2006.

27. Aicher, J.; Asiimwe, F.; Batchuluun, B.; Hauschild, M.; Zöhrer, M.; Egger, R. Online Hotel Reviews: Rating Symbols or Text ... Text or Rating Symbols? That is the Question! In Information and Communication Technologies in Tourism; Springer: Cham, Switzerland, 2016; pp. 369-382.

28. Hao, J.X.; Tang, R.; Yu, Y.; Li, N.; Law, R. Visual Appeal of Hotel Websites: An Exploratory Eye Tracking Study on Chinese Generation Y. In Information and Communication Technologies in Tourism; Springer: Cham, Switzerland, 2015; pp. 607-620. 
29. Noone, B.; Robson, S.K.A. Using eye tracking to obtain a deeper understanding of what drives online hotel choice [Electronic article]. Cornell Hosp. Rep. 2014, 14, 6-16.

30. Pan, B.; Zhang, L.; Smith, K. A mixed-method study of user behavior and usability on an online travel agency. Inf. Technol. Tour. 2011, 13, 353-364. [CrossRef]

31. Wang, T.C.; Tsai, C.L.; Tang, T.W. Restorative quality in tourist hotel marketing pictures: Natural and built characteristics. Curr. Issues Tour. 2018. [CrossRef]

32. Duchowski, A.T. Eye Tracking Methodology: Theory and Practice; Springer Science \& Business Media: Berlin, Germany, 2007.

33. Orquin, J.L.; Loose, S.M. Attention and choice: A review on eye movements in decision making. Acta Psychol. 2013, 144, 190-206. [CrossRef] [PubMed]

34. Pieters, R.; Rosbergen, E.; Wedel, M. Visual attention to repeated print advertising: A test of scanpath theory. J. Mark. Res. 1999, 36, 424-438. [CrossRef]

35. Wedel, M.; Pieters, R. Visual Marketing: From Attention to Action; Psychology Press: New York, NY, USA, 2012.

36. Rayner, K.; Miller, B.; Rotello, C.M. Eye movements when looking at print advertisements: The goal of the viewer matters. Appl. Cognit. Psychol. 2008, 22, 697-707. [CrossRef] [PubMed]

37. Atalay, A.S.; Bodur, H.O.; Rasolofoarison, D. Shining in the center: Central gaze cascade effect on product choice. J. Consum. Res. 2012, 39, 848-866. [CrossRef]

38. Li, Q.; Huang, Z.J.; Christianson, K. Visual attention toward tourism photographs with text: An eye-tracking study. Tour. Manag. 2016, 54, 243-258. [CrossRef]

39. Wang, T.C.; Tang, T.W.; Cheng, J.S. Art-oriented model of hotel service innovation. Int. J. Contemp. Hosp. Manag. 2018, 30, 160-177. [CrossRef]

40. Bahia, K.; Paulin, M.; Perrien, J. Reconciling literature about client satisfaction and perceived service quality. J. Prof. Serv. Mark. 2000, 12, 21-41.

41. Nadeau, J.; Heslop, L.; O’Reilly, N.; Luk, P. Destination in a country image context. Ann. Tour. Res. 2008, 35, 84-106. [CrossRef]

42. Van den Berg, A.E.; Joye, Y.; Koole, S.L. Why viewing nature is more fascinating and restorative than viewing buildings: A closer look at perceived complexity. Urban For. Urban Green. 2016, 20, 397-401. [CrossRef]

43. Purcell, A.T.; Peron, E.; Berto, R. Why do preferences different between scene types? Environ. Behav. 2001, 33, 93-106. [CrossRef]

44. Van den Berg, A.E.; Hartig, T.; Staats, H. Preference for nature in urbanized societies: Stress, restoration, and the pursuit of sustainability. J. Soc. Issues 2007, 63, 79-96. [CrossRef]

45. Kaplan, S.; Kaplan, R.; Wendt, J.S. Rated preference and complexity for natural and urban visual materials. Percept. Psychophys. 1972, 12, 354-356. [CrossRef]

46. Goodman-Deane, J.; Waller, S.; Latham, K.; Price, H.; Tenneti, R.; Clarkson, P.J. Differences in vision performance in different scenarios and implications for design. Appl. Ergon. 2016, 55, 149-155. [CrossRef] [PubMed]

47. Law, S.; Braun, K.A. I'll have what she's having: Gauging the impact of product placements on viewers. Psychol. Mark. 2000, 17, 1059-1075. [CrossRef]

48. Scott, N.; Zhang, R.; Le, D.; Moyle, B. A review of eye-tracking research in tourism. Curr. Issues Tour. 2017. [CrossRef]

49. Harris, L.C.; Ezeh, C. Servicescape and loyalty intentions: An empirical investigation. Eur. J. Mark. 2008, 42, 390-422. [CrossRef]

50. Hair, J.F.; Anderson, R.L.; Tatham, W.C. Multivariate Data Analysis with Reading; Prentice-Hall: Upper Saddle River, NJ, USA, 1998.

51. Fornell, C.; Larcker, D.F. Evaluating structural equation models with unobservable variables and measurement error. J. Mark. Res. 1981, 18, 39-50. [CrossRef]

52. Johnston, R. Service transaction analysis: Assessing and improving the customers experience. Manag. Serv. Qual. 1999, 9, 102-109. [CrossRef]

53. Hartig, T.; Mitchell, R.; De Vries, S.; Frumkin, H. Nature and health. Ann. Rev. Public Health 2014, 35, $207-228$. [CrossRef] [PubMed] 
54. Margaryan, L.; Fredman, P. Natural amenities and the regional distribution of nature-based tourism supply in Sweden. Scand. J. Hosp. Tour. 2016, 17, 145-159. [CrossRef]

55. Hume, M.; Mort, G.S.; Winzar, H. Exploring repurchase intention in a performing arts context: Who comes? and why do they come back? Int. J. Nonprofit Volunt. Sect. Mark. 2007, 12, 135-148. [CrossRef]

(c) 2018 by the authors. Licensee MDPI, Basel, Switzerland. This article is an open access article distributed under the terms and conditions of the Creative Commons Attribution (CC BY) license (http:/ / creativecommons.org/licenses/by/4.0/). 